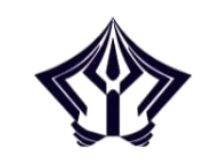

ANFUSINA: JOURNAL OF PSYCHOLOGY

http://ejournal.radenintan.ac.id/index.php/anfusina

DOI: //dx.doi.org/10.24042/ajp.v2i1.4151

Volume 2, Nomor 1, April Tahun 2019

\title{
Hubungan antara Persahabatan dengan Attachment Ayah dan Ibu
}

\author{
Renyep Proborini \\ Fakultas Psikologi Universitas Muhammadiyah Lampung \\ rproborini66@gmail.com
}

\begin{abstract}
Making friends is a high-level ability in social relations. In friendship, individuals approach, open up, share, understand differences and accept each other. The ability to make friends is formed by the relationship between parents - children. Attachment between parents and children is the basis for forming a person's personality, including making friendships. This study aims to measure the relationship between friendship and father's attachment and maternal attachment. As the dependent variable is friendship, while the independent variable is father's attachment and maternal attachment. Measurement of the three variables using a likert scale. The research subjects were students of the Faculty of Psychology, University of Muhammadiyah Lampung. This research used incidental sampling technique, with 60 students became participants. Data were analyzed using descriptive test and multiple regression test. The results of the study showed that the majority of the students of the Psychology Faculty UM Lampung had the ability to make good friendships, attachment with comfortable mothers and fathers. Attachment with mother is higher than with father. Mother as the main attachment figure, has a closer and more comfortable relationship with the subject than the father's relationship with the subject.Testing of the three hypotheses shows that there is no relationship between friendship and mother's attachment, friendship with father's attachment and friendship with attachments of father and mother together.
\end{abstract}




\begin{abstract}
Abstrak
Menjalin persahabatan merupakan kemampuan level tinggi dalam relasi sosial. Dalam persahabatan, individu lebih mendekat, membuka diri, berbagi, memahami adanya perbedaan dan saling menerima. Kemampuan menjalin persahabatan terbentuk dari hubungan antara orang tua - anak. Attachment atau kelekatan antara orang tua-anak menjadi dasar dari pembentukan kepribadian seseorang, termasuk menjalin persahabatan. Penelitian ini bertujuan untuk mengukur hubungan antara persahabatan dengan attachment ayah dan attachment ibu. Sebagai variabel bergantung adalah persahabatan, sedangkan variabel bebas yaitu attachment ayah dan attachment ibu. Pengukuran ketiga variabel dengan menggunakan skala Likert. Subyek penelitian adalah mahasiswa Fakultas Psikologi Universitas Muhammadiyah Lampung. Sampel penelitian diambil dengan menggunakan teknik incidental sampling. Sebanyak 60 mahasiswa yang menjadi sampel penelitian. Analisa data dilakukan dengan uji deskriptif dan uji inferensial yaitu regresi berganda. Hasil penelitian menunjukkan bahwa mayoritas mahasiswa Fakultas Psikologi UM Lampung memiliki kemampuan menjalin persahabatan yang baik, attachment dengan ibu dan ayah yang nyaman. Attachment dengan ibu lebih tinggi dibandingkan dengan ayah. Ibu sebagai figur kelekatan yang utama, memilki hubungan yang lebih erat dan nyaman bersama subyek dibandingkan hubungan ayah dengan subyek. Pengujian ketiga hipotesis menunjukkan bahwa tidak ada hubungan antara persahabatan dengan attachment ibu, persahabatan dengan attachment ayah serta persahabatan dengan attachment ayah dan ibu secara bersama-sama
\end{abstract}

Keyword: friendship, mother's attachment, and father's attachment.

\title{
Pendahuluan
}

Sahabat adalah teman yang akrab, sering bersama dan saling mendukung (Santrock, 2007). Sahabat lebih akrab dan erat hubungannya daripada sekedar teman atau kawan. Persahabatan merupakan hal penting bagi remaja dan berlanjut di fase dewasa awal. Penelitian mengenai persahabatan menunjukkan bahwa remaja lebih banyak menceritakan pengalaman pribadinya dibandingkan anakanak (Buhrmester \& Furman, 1987 dalam Santrock). Remaja yang memiliki sahabat menjadi lebih bahagia dibandingkan remaja yang tidak memiliki sahabat (Buhrmester, 1990; Yin, Buhrmester \& Hibbard, 1996 dalam Santrock 2007). Gotman dan Parker (dalam Santrock, 2007) menyimpulkan bahwa fungsi persahabatan meliputi:1)Kebersamaan, yang mana individu menghabiskan waktu untuk melakukan kegiatan bersama dan saling menyenangkan, 2) Stimulasi berupa saling memberikan informasi dan kegembiraan, 3) 
Dukungan dan bantuan yang diberikan secara fisik, 4) Ego support untuk membangun harga diri, 5) Perbandingan social, persabahatan memberikan pemahaman mengenai posisi individu di lingkungannya, apakah bermasalah ataukah tidak, (6) Intimasi/afeksi, persahabatan memberikan perhatian dan kasih sayang, membangun relasi yang hangat dan menyenangkan.

Pada orang dewasa awal, persahabatan merupakan perwujudan dari kemampuan untuk menjalin relasi secara intim. Menurut Papalia, Olds, Feldman (2009) persahabatan pada orang dewasa awal melibatkan kepercayaan, penghargaan, pemahaman, penerimaan, berbagi kegembiraan, kesediaan untuk membantu, dan spontanitas. Meskipun intensitas kebersamaan dalam persahabatan semakin berkurang pada masa dewasa awal jika dibandingkan dengan masa remaja, namun persahabatan menjadi proses yang penting bagi orang dewasa untuk menjalin hubungan yang lebih dekat dan spesifik, terutama ketika menikah. Hubungan yang akrab dengan orang lain, yang memungkinkan bagi individu untuk membuka diri, memberikan konsekuensi meningkatnya kesadaran akan identitas diri sekaligus kemandirian (Papalia, Olds, Felman, 2009; Santrock, 2002).

Kenyamanan bersama orang lain, membuka diri, merasa dibutuhkan dan membutuhkan orang lain, erat kaitannya dengan attachment individu dengan orang tuanya. Helmi (2004) mengungkapkan tentang teori attachment dari Bowlby dan Ainsworth. Bowlby menemukan adanya pola hubungan antara bayi dan anak dengan ibu sebagai pengasuh utama. Menurut Ainsworth attachment adalah ikatan afeksional antara anak dengan figure lekat yaitu ibu. Ikatan ini tetap ada, meskipun anak berpisah dengan figure lekatnya. Bowlby dan Ainsworth menyatakan bahwa hubungan yang mesra dan saling mempercayai antara bayi dengan figur utama kelekatan yaitu ibu, merupakan model internal yang akan menjadi cetakan bagi individu untuk berinteraksi dengan lingkungannya.

Berbagai penelitian tentang attachment menunjukkan adanya keterkaitan dengan perkembangan kepribadian, kualitas relasi sosial, kehidupan berorganisasi serta tingkat stres (Rubinstein, Tziner, dan Bilig, 2012). Laumi dan Adiyanti (2012) menemukan bahwa attachment remaja dengan ayah, ibu dan teman sebaya, berhubungan dengan self-esteem. Nunes, Faraco, dan Vieira (2013) mendapati bahwa kurangnya kelekatan dengan ibu, menyebabkan agresi dan kenakalan pada anak laki-laki. Sedangkan kurangnya kelekatan dengan ayah akan berpengaruh terhadap perlaku menghindar serta depresi pada anak laki-laki. 
Klomek, Rubin, Yagon, Berkowitz, Apter, dan Mikulicer (2016) meneliti pada anak sekolah menengah, yang mengalami kesulitan belajar/ learning disorder (LD) serta ADHD atau attention deficit hyperactive disorder. Remaja yang mengeluhkan dirinya mengalami LD dan ADHD memiliki resiko tinggi untuk dibuli dibandingkan remaja yang tidak mengalami LD atau ADHD. Hasil penelitian menunjukkan bahwa secure attachment dengan ibu berhubungan dengan rendahnya kasus buli pada anak dengan gangguan LD dan ADHD. Sedangkan attachment dengan ayah dan guru, tidak memiliki hubungan yang signifikan dengan peluang dibuli pada remaja.

Penelitian attachment terhadap orang tua oleh Ruckstaetter, Sells, dan Newmeyer (2017) menunjukkan bahwa secure attachment ditemukan pada orang tua yang pemaaf. Pemaafan tersebut memunculkan empati serta rasa bersalah serta menekan rasa malu dan menghindar.

Penelitian attachment pada akhirnya melebar ke berbagai lingkup psikologi secara lebih meluas. Penelitian attachment dengan Allah dihubungkan dengan komitmen terhadap tempat kerja/organisasi (Kent, 2017). Kent meneliti pada sejumlah penganut agama yang berbeda dan menyimpulkan bahwa terdapat perbedaan komitmen terhadap organisasi antara agama yang berbeda. Wright (2017) meneliti sarjana yang baru lulus dengan berfokus pada hubungan antara tipe attachment dengan self-efficacy dalam pencarian karir. Aktivitas dalam mencari karir yang dimaksud adalah menjalani interviu, networking, melamar pekerjaan, dan eksplorasi personal. Hasil penelitian menunjukkan bahwa anxious attachment memiliki korelasi negatif dengan self-efficacy saat interviu. Avoidant attachment berkorelasi negatif dengan self-efficacy untuk melakukan networking, melamar pekerjaan, dan eksplorasi personal.

Dari berbagai penelitian mengenai attachment di atas, menunjukkan bahwa attachment yang terbentuk ketika bayi diasuh dan diurus oleh ibu, telah terbukti tetap memberikan pengaruh ketika bayi beranjak besar, menjadi anak dan bahkan ketika sudah dewasa. Pengaruh attachment terhadap perkembangan kepribadian, pada akhirnya menjadi meluas karena dinamika kepribadian sebagai hasil interaksi dengan lingkungan serta konsekuensi dari munculnya berbagai permasalahan yang mengiringi interaksi tersebut. Ketika attachment diteliti secara terpisah antara ayah dan ibu, didapati bahwa ada perbedaan pengaruh di antara keduanya. 
Penelitian ini dilakukan untuk lebih memperluas hasil penelitian-penelitian sebelumnya, terutama untuk melihat pengaruh dari attachment ayah dan ibu, yang dihubungkan dengan persahabatan. Tujuan penelitian untuk mengukur: 1) Hubungan antara attachment ayah dengan persahabatan, 2) Hubungan antara attachment ibu dengan persahatan, 3) Hubungan antara attachment ayah, ibu dengan persahabatan.

\section{Metode Penelitian}

Penelitian ini menggunakan metode kuantitatif, dengan populasi mahasiswa Fakultas Psikologi Universitas Muhammadiyah Lampung. Pemilihan subjek penelitian ini didasari atas pertimbangan bahwa persahabatan dan kemampuan menjalin relasi sosial merupakan salah satu capaian pembelajaran Fakultas Psikologi Universitas Muhammadiyah Lampung. Pada kenyataannya, berdasarkan observasi dan wawancara, sejumlah mahasiswa Fakultas Psikologi UM Lampung kurang mampu berbaur, menyendiri, dan kesulitan untuk membuka diri.

Pengambilan sampel menggunakan teknik incidental sampling, yaitu mahasiswa semester II, IV, dan VI dan VIII yang ditemui di kampus pada saat pengambilan data. Jumlah sampel yang berhasil dikumpulkan sebesar 60 orang.

Variabel penelitian terdiri dari variabel bergantung yaitu persahabatan, variabel bebas yaitu attachment ayah dan attachment ibu. Masing-masing variabel diukur dengan menggunakan skala likert. Subjek penelitian diminta untuk memilih salah satu dari lima alternatif jawaban, yaitu tidak pernah, jarang, kadang-kadang, sering dan selalu.

Skala 1: mengukur persahabatan, yaitu persepsi mahasiswa terhadap hubungannya dengan teman akrab, meliputi kepercayaan, penghargaan, pemahaman, penerimaan, berbagi kegembiraan, kesediaan untuk membantu, mempercayai, dan spontanitas.

Contoh aitem antara lain:

- Saya berbelanja ataupun makan bersama dengan teman akrab

- Jika ada kejadian yang tidak menyenangkan, saya tidak pernah menceritakan pada siapapun.

- Saya paham dengan perasaan teman akrab saya.

Skala 2: mengukur attachment ayah, yang mana mahasiswa diminta untuk menilai hubungan dirinya dengan ayah, sepanjang yang 
diingat. Pengukuran attachment didasari dari tiga aspek kognisi, afeksi, dan perilaku yang merupakan perwujudan dari upaya ayah untuk mendekat, melindungi dan memberikan rasa aman bagi anak.

Contoh aitem antara lain:

- Ayah mengajak saya untuk melakukan aktivitas bersama

- Ayah bercerita tentang masa kecilku yang lucu

- Ayah memeluk saya ketika saya sedih

Skala 3: mengukur attachment ibu, yang mana mahasiswa diminta untuk menilai hubungan dirinya dengan ibu, sepanjang yang diingat. Skala ini merupakan variasi dari skala 1, dengan ibu sebagai figur lekatnya. Aspek dan indicatornya sama dengan skala 2.

Contoh aitem antara lain:

- Ibu mengajak saya untuk melakukan aktivitas bersama

- Ibu bercerita tentang masa kecilku yang lucu

- Ibu memeluk saya ketika saya sedih

Alat ukur distandarisasi dengan uji validitas dan reliabilitas. Uji reliabilitas terhadap skala attachment ayah diperoleh Cronbach alpha 0.918, skala attachment ibu dengan cronbach alpha 0.896, serta skala persahabatan dengan cronbach alpha 0.76. Dengan angka alpha di atas 0.75 menunjukkan bahwa ketiga skala tersebut memiliki keajegan yang kuat.

Analisa data dilakukan dengan menggunakan teknik statistik regresi berganda serta analisa deskriptif. Analisa deskriptif untuk memberikan gambaran mengenai kemampuan menjalin persahabatan serta mengukur attachment ayah dan ibu pada sampel. Uji regresi berganda untuk menguji ketiga hipotesis. Hipotesis penelitian, yaitu: 1) Ada hubungan antara persahabatan dengan attachment ayah, 2) Ada hubungan antara persahabatan dengan attachment ibu, dan 3) Ada hubungan antara persahabatan dengan attachment ayah dan ibu.

\section{Hasil dan Pembahasan}

Hasil uji deskriptif terhadap tiga variabel, yaitu attachment ayah, ibu, serta persahabatan tertuang dalam tabel berikut.

Tabel 1. Hasil Deskriptif Statistik.

\begin{tabular}{lcc}
\hline & $\boldsymbol{M}$ & $\boldsymbol{S} \boldsymbol{D}$ \\
\hline Attachment Ayah & 68.57 & 13.59 \\
\hline Attachment Ibu & 80.33 & 11.12 \\
\hline Persahabatan & 57.50 & 4.75 \\
\hline
\end{tabular}


Rata-rata attachment ayah 68.57 dan attachment ibu 80.33. Hal ini bermakna mahasiswa lebih erat dan nyaman hubungannya dengan ibu dibandingkan dengan ayah. Ibu sebagai figur utama attachment, terbukti dalam penelitian ini.

Kategorisasi ke dalam level dari ketiga variabel, dibuat dengan mengelompokkan data empiris sesuai dengan standar hipotetik. Tabel 2 menunjukkan hasil kategorisasi tersebut.

Tabel 2. Level attachment ayah, ibu dan persahabatan

\begin{tabular}{lcccccc}
\hline \multicolumn{1}{c}{ Level } & \multicolumn{2}{c}{$\begin{array}{c}\text { Attachment } \\
\text { ayah-anak }\end{array}$} & \multicolumn{2}{c}{$\begin{array}{c}\text { Attachment ibu- } \\
\text { anak }\end{array}$} & \multicolumn{2}{c}{ Persahabatan } \\
& $\boldsymbol{f}$ & $\mathbf{\%}$ & $\boldsymbol{f}$ & $\boldsymbol{\%}$ & $\boldsymbol{f}$ & $\boldsymbol{\%}$ \\
\hline Rendah & 1 & $1,7 \%$ & 0 & 0 & 0 & 0 \\
\hline Agak rendah & 11 & $18,3 \%$ & 2 & $3,3 \%$ & 0 & 0 \\
\hline Sedang & 26 & $43,3 \%$ & 19 & $31,7 \%$ & 16 & $\begin{array}{c}26,7 \\
\%\end{array}$ \\
\hline Agak tinggi & 21 & $35,0 \%$ & 31 & $51,7 \%$ & 43 & $\begin{array}{c}71,7 \\
\%\end{array}$ \\
\hline Tinggi & 1 & $1,7 \%$ & 8 & $13,3 \%$ & 1 & $1,7 \%$ \\
\hline
\end{tabular}

Attachment antara mahasiswa dengan ayah, mayoritas di level sedang dengan skor $43.3 \%$, disusul di level agak tinggi 35\%, agak rendah $18.3 \%$, level rendah dan tinggi masing-masing $1.7 \%$. Mayoritas mahasiswa cukup lekat dan cukup nyaman dengan ayah. Secara kognitif, emosi dan perilaku, ada kedekatan dengan ayah. Hanya ada satu mahasiswa di antara 60 sampel yang sangat lekat dan sangat nyaman dengan ayahnya. Kurang adanya kelekatan dan kurang nyaman bersama ayah, diakui oleh 12 orang atau $20 \%$ dari sampel (agak rendah $18.3 \%$ dan rendah $1.7 \%$ ).

Attachment mahasiswa dengan ibu, mayoritas di level agak tinggi dengan skor $51.7 \%$. Berikutnya di level sedang $31.7 \%$, level tinggi $13.3 \%$ dan agak rendah $3.3 \%$. Tidak ada attachment mahasiswa dengan ibu yang berada di level rendah. Hubungan antara mahasiswa dengan ibu terjalin dengan erat dan positif. Baik secara kognitif, emosi maupun perilaku, ibu mampu mengekspresikan perhatian dan rasa sayangnya pada anak, yang dalam hal ini adalah mahasiswa. Mahasiswa lebih lekat dengan ibu bila dibandingkan dengan ayah. Secara umum, hubungan antara mahasiswa dengan orang tuanya terbina dengan baik. Adanya saling mempercayai di antara mereka. 
Kemampuan menjalin persahabatan pada mahasiswa Fakultas Psikologi UM Lampung sebagian besar pada kategori agak tinggi, yaitu sebesar $71.7 \%$. Berikutnya di level sedang $26.7 \%$ dan level tinggi $1.7 \%$. Sedangkan level rendah dan agak rendah, tidak ada. Hal ini menunjukkan bahwa mahasiswa Fakultas Psikologi mampu membuka diri, saling menerima, memahami, mempercayai, menghargai dan bersikap spontan pada sebagian teman yang menjadi sahabat. Mahasiswa mampu mendekat dan membina hubungan yang akrab dan mengarah pada komitmen. Tidak ada mahasiswa yang kesulitan dalam menjalin hubungan dengan teman akrabnya.

Hasil uji regresi berganda dapat dilihat pada Tabel 3 berikut ini.

Tabel 3. Hasil Uji Regresi Berganda.

\begin{tabular}{cccc}
\hline $\mathrm{R}$ & R Square & Adjusted R Square & $\begin{array}{c}\text { Std. Error of the } \\
\text { Estimate }\end{array}$ \\
\hline .254 & .064 & .031 & 4.678 \\
\hline
\end{tabular}

Tabel 3. Hasil Uji ANOVA.

\begin{tabular}{lccccc}
\hline & Sum of Squares & df & Mean Square & F & Sig. \\
\hline Regression & 85.704 & 2 & 42.852 & 1.958 & .150 \\
\hline Residual & 1247.296 & 57 & 21.882 & & \\
\hline Total & 1333.000 & 59 & & & \\
\hline
\end{tabular}

Tabel 4. Koefisien.

\begin{tabular}{lccccc}
\hline & \multicolumn{2}{c}{$\begin{array}{l}\text { Unstandardized } \\
\text { Coefficients }\end{array}$} & \multicolumn{2}{l}{$\begin{array}{l}\text { Standardized } \\
\text { Coefficients }\end{array}$} & \\
& $\mathrm{B}$ & Std. Error & Beta & $\mathrm{t}$ & Sig. \\
\hline (Constant) & 49.078 & 4.509 & & 10.884 & .000 \\
\hline Attach_ayah & .050 & .054 & .142 & .926 & .359 \\
\hline Attach_ibu & .062 & .066 & .146 & .954 & .344 \\
\hline
\end{tabular}

Berdasarkan Tabel 3, $\mathrm{R}=0.254$ bermakna bahwa korelasi antara persahabatan dengan attachment ayah dan ibu sebesar 0.254. Menurut Piaw (2006), rentang korelasi $0.1-0.30$ tergolong sangat 
lemah. $\mathrm{R}^{2}=0.064$ menunjukkan bahwa pengaruh attachment ayah dan attachment ibu secara bersama-sama memberikan pengaruh sebesar $6.4 \%$. Pengaruh ini sangat kecil dan sebagian besar dipengaruhi oleh faktor lain yang tidak diteliti.

Lemahnya hubungan antara variabel bergantung dengan kedua variabel bebas, diperkuat dengan skor $\mathrm{F}=1.958$ dengan $\alpha=$ 0.15 di mana $\alpha$ lebih besar dari tingkat kepercayaan yang dijadikan standard 0.05. Hal ini menunjukkan bahwa adanya perubahan pada skor persahabatan tidak dapat ditentukan oleh attachment kedua orang tua. Dengan demikian dapat disimpulkan bahwa hipotesis ketiga tidak terbukti. Tidak ada hubungan antara persahabatan dengan attachment ayah dan ibu

Hubungan antara persahabatan dengan attachment ayah, dapat dilihat pada nilai t pada attachment ayah $=0.926$ dengan $\alpha=$ 0.359. Hal ini bermakna bahwa perubahan skor persahabatan tidak dapat diprediksikan oleh perubahan skor attachment ayah. Hipotesis pertama tidak terbukti, sehingga tidak ada hubungan antara persahabatan dengan attachment ayah

Hipotesis kedua, yaitu ada hubungan antara persahabatan dengan attachment ibu, juga tidak terbukti. Nilai t pada attachment $\mathrm{ibu}=0.954$ dengan $\alpha=0.344$. Perubahan skor persahabatan tidak dipengaruhi oleh skor attachment ibu.

Hasil penelitian ini menunjukkan hubungan antara persahabatan dengan attachment ayah dan attachment ibu, sangat lemah dan tidak signifikan. Perubahan pada attachment ayah dan ibu tidak dapat dijadikan prediktor terhadap perubahan kemampuan menjalin persahabatan. Hasil ini berbeda dengan teori tentang attachment ataupun penelitian-penelitian terdahulu. Buren dan Cooley (2002) menyatakan bahwa attachment dengan figur lekat menjadi model mental kelekatan yang akan mempengaruhi perilaku seseorang hingga dewasa. Model mental ini sudah terlebih dahulu diungkapkan oleh Bowlby dan Ainsworth (dalam Helmi, 2004). Dengan adanya pola interaksi dengan figur lekat maka individu akan menerapkan pola tersebut ketika berinteraksi dengan orang lain, mulai dari fase anak hingga dewasa. Attachment positif dengan orang tua akan membantu individu untuk menjalin hubungan yang akrab dan nyaman dengan temannya.

Dalam penelitian ini didapati bahwa sebagian besar subjek penelitian memiliki attachment yang baik, terutama dengan ibu. 
Meskipun, 20\% subyek menyatakan memiliki hubungan dengan ayah yang berjarak, kurang terbuka dan kurang nyaman. Kemampuan menjalin persahabatan yang baik, dimiliki oleh mayoritas subjek. Artinya, secara umum hubungan yang hangat, terbuka, dan nyaman dengan orang tua, mampu membentuk kemampuan untuk menjalin hubungan yang hangat, terbuka dan nyaman dengan teman. Namun demikian, hal ini tidak terbukti dalam penelitian ini.

Sejumlah data yang dikumpulkan dalam proses penelitian ini diduga berkaitan dengan tidak adanya hubungan antara attachment dengan persahabatan. Skala persahabatan yang diberikan kepada subjek, pengukurannya berfokus pada hubungan dengan teman akrab. Artinya, ketika memilih alternatif jawaban, didasari atas persepsi subjek terhadap hubungannya dengan satu atau beberapa orang sahabat. Skala ini tidak mengukur kemampuan subyek dalam membina hubungan dengan teman dalam lingkup yang lebih luas. Pada kenyataannya, melalui observasi dan wawancara ditemukan bahwa beberapa subjek kurang mampu berbaur dengan teman sekelasnya, namun mampu menjalin hubungan yang akrab dengan 1-2 teman. Hal ini bermakna bahwa fokus penelitian ini hanya pada kualitas hubungan pertemanan dan tidak mengukur kemampuan secara kuantitas.

Ketiadaan pengukuran terhadap kualitas hubungan pertemanan dalam lingkup yang luas, bukan hanya sahabat melainkan juga teman, dapat menyebabkan subyek kurang mampu memberikan penilaian secara proporsional. Peluang terjadinya bias, menjadi cukup besar. Subyek mempersepsikan bahwa hubungannya sangat terbuka dan mampu menerima sahabatnya apa adanya, meski kenyataannya tidak sebesar yang dipersepsikan.

Pengukuran attachment dalam penelitian ini berfokus pada kualitas kelekatan, yaitu adanya hubungan yang erat, hangat, penerimaan dan penghargaan. Hasil pengukuran attachment hanya akan menunjukkan bahwa antara ayah/ibu dengan mahasiswa dekat ataukah tidak, adanya saling membutuhkan, memperhatikan, dan sebagainya. Penelitian ini tidak mengkategorikan tipe attachment menjadi secure dan insecure, ataupun membedakan dalam anxiety dan avoidant sebagaimana menurut Bowlby. Berdasarkan kategori yang dibuat oleh Bowlby, masing-masing tipe attachment memiliki ciri-ciri yang berbeda. Kelekatan yang 
kuat antara anak dan orang tua, tidak selalu berdampak positif bagi pengembangan kepribadian. Seperti misalnya anxiety attachment yang ditandai dengan kebutuhan yang besar akan kehadiran figur lekat namun diwarnai oleh kecemasan, akan berdampak pada munculnya kecemasan yang signifikan pada anak. Dengan keterbatasan pengukuran attachment dalam penelitian ini maka kurang dapat diketahui apakah kedekatan hubungan antara subyek dengan orang tuanya diwarnai oleh perasaan aman /nyaman ataukah tidak aman/tidak nyaman. Batasan penelitian seperti tersebut di atas, diperkirakan turut berpengaruh terhadap hasil penelitian yaitu tidak terbuktinya hipotesis.

\section{Simpulan dan Saran}

Hasil penelitian ini dapat disimpulkan bahwa tidak ada hubungan antara persahabatan dengan attachment ayah dan attachment ibu pada mahasiswa Fakultas Psikologi Universitas Muhammadiyah Lampung.

Saran bagi penelitian selanjutnya adalah:

a. Pengukuran attachment dengan pengelompokan tipe attachment yaitu secure attachment dan insecure attachment.

b. Pengukuran persahabatan dapat ditambahkan dengan pertemanan, sehingga dapat diukur dengan lebih luas dan menyeluruh.

\section{Referensi}

Buren, A.V., \& Cooley, E. L. (2002). Attachment style, view of self, and negative affect. North American Journal of Psychology, 3, 417-430.

Helmi, A. F. (2004). Model teoritik gaya kelekatan atribusi, respon emosi, dan perilaku marah. Buletin Psikologi, 12 (2).

Kent, B. V. (2017). Attachment to god, religious tradition, and firm attributes in workplace comitment. Journal of Social Psychology, 157 (4), 485-501.

Laumi., Adiyanti, M. G. (2012). Attachment of late adolescent to mother, father, and peer, with family structure as moderating 
variable and their relationships with self-esteem. Jurnal Psikologi, 39 (2), 129-142.

Nunes, S. A. N., Faraco, A. M. X., Vieira, M. L. (2013). Attachment and parental practices as predictor of behavioral disorder in boys and girls, Paidèia, 23 (56), 369-377. doi: 10.1590/198243272356201311.

Papalia, Olds, Feldman. (2009). Human development: Perkembangan manusia ( $2^{\text {nd }}$ ed.) Jakarta: Salemba Humanika.

Piaw, C. Y., (2006). Asas statistik penyelidikan. Kuala Lumpur: Mc Graw Hill.

Ruckstaetter, J., Sells, J., Newmeyer, M. (2017). Parental apologies, empathy, shame, guilt, and attachment: A path analysis. Journal of Counselling Development, 95 (10).

Rubinstein, G., Tziner, A., Bilig, M. (2012). Attachment, relationship quality and stressful life events: A theoretical meta-perspective and some preliminary results. Revista de Psicologia del Trabajo y de Las Organizaciones, 28 (3), 1576-5962.

Santrock, J, W., (2007). Remaja (11 ${ }^{\text {th }}$ ed.). Jakarta: Erlangga

Santrock, J. W., (2002). Life-span development perkembangan masa hidup ( $2^{\text {nd }}$ ed.). Jakarta: Erlangga

Wright, S. L. (2017). Attachment and self-efficacy in career search activity: A structural model. The Career Development Quarterly, 65, doi: 10.1002//cdq.12085. 